\title{
Present status of fish farming and pond conditions from Basti and Gonda districts, Uttar Pradesh
}

*Sunil Kumar Upadhyay and J. Mishra

\author{
Department of Zoology, \\ M. D. (P.G.) College, \\ PRATAPGARH-230001 (U.P.), INDIA \\ *Corresponding Author \\ Email : sunilupadhyay179@gmail.com
}

Received : 10.02.2020; Accepted : 04.04.2020

\begin{abstract}
Fish ponds operate as an open ecological system where natural and technological processes are built on one another and are implemented in a non-separable way. Pond fish farms contribute to preserve biodiversity. In both districts the composite fish culture technology is commonly followed for fish farming with six species combination i.e. Indian Major Carps (IMC) i.e. Catla, Rohu and Mrigal (Nain) and Exotic Major Carps (EMC) i.e. Silver carp, Grass carp and Common carp. There are 14 blocks in Basti district in which 3848 number of ponds are found. These ponds cover 1040.42 ha of water spread area. There are 16 blocks in Gonda district. The number of ponds is 4471 with water spread area of 3706.86 ha. The total productions of fishes are 1800 ton/year in Basti district while 3850 ton/year in Gonda district. The average productions are $2800 \mathrm{~kg} / \mathrm{ha} / \mathrm{year}$ and $3000 \mathrm{~kg} / \mathrm{ha} / \mathrm{year}$ in Basti and Gonda districts, respectively. The data indicated that the Gonda district have more potential in fish production compared to Basti district. The maximum ponds were of less than 1 hectare in both districts. The respondents were $68 \%$ in Basti district and 76\% in Gonda District. 82\% and 70\% respondents have leased pond in Basti and Gonda districts, respectively. Gonda district has more potential for fishing in future.

\section{Introduction}

The importance of fish as a source of high quality and easily digestible protein, essential amino acids and poly unsaturated fatty acid is well understood ${ }^{3,6,24}$. It is argued that fish meat is generally cheaper than other animal's meat and contains protein levels of $17-20 \%$ as well as sufficient amount of minerals and vitamins $4,13,25$. India offers a huge potential for freshwater aquaculture development. The Indian freshwater fish culture has evolved from the stage of domestic activity in West Bengal and Odisha to that of an industry in recent years. The states like Andhra Pradesh, Punjab, Haryana, Maharashtra, Bihar and Uttar Pradesh are taking up fish culture as a trade. The fish culture industry has grown at a significant rate over the last few decades. With the help of technological inputs, entrepreneurship initiatives and financial investment, the fish production has gone up from $600-800 \mathrm{~kg} /$ ha per year to $10-12$ tonnes/ha/year in the several parts of the country with the national average production of $2450 \mathrm{~kg} / \mathrm{ha} / \mathrm{year}^{2}$.

Ponds are shallow water bodies of standing water. Pond water is a primary unit of inland fish production ${ }^{11,14}$. Small perennial water bodies such as ponds and tanks are maintaining biodiversity and provide help for recharging of river in monsoon season ${ }^{16,26}$. Wild ponds are rich in plankton biodiversity compared to managed ponds ${ }^{22}$. These water bodies are also providing huge food security and livelihoods of peoples globally ${ }^{8,9}$. Pond aquaculture technology can be summarized as a complex value, important for nature conservation, water management and socio-economic aspects as well. Pond aquaculture is a good example for natural resources renewing technology and the circular economy. Pond fish farms besides producing fish provide ecosystem service. Ponds get their energy from the sun and develop own ecological phenomena with help of substratum nature (e.g., productivity).

Uttar Pradesh has vast potential of aquatic bioresources and offers considerable scope of inland fisheries development and aquaculture ${ }^{15,18,19}$. Inland fish production of India reached $12.5 \mathrm{~m}$ tones with help of scientific technology but this technology applies only in developed states while in developing states fish cultivation has done mostly with the traditional system. Indian and exotic major carps are backbone of culture fishery in Indian ${ }^{10}$. These species are also economically important 
TABLE-1: Basti and Gonda districts of eastern Uttar Pradesh, their blocks and villages for the study

\begin{tabular}{|c|c|c|c|}
\hline & Basti District & & da District \\
\hline Blocks & Villages & Blocks & Villages \\
\hline Sadar & $\begin{array}{l}\text { Ganeshpur, Mishraulia, } \\
\text { Markatiya, Ranipur }\end{array}$ & Jhajhari & $\begin{array}{l}\text { Banrasia, Dautalpur, Kasavpur } \\
\text { phaha }\end{array}$ \\
\hline Saughat & Machuwa, Rasana, Tareta & Padrikripal & $\begin{array}{l}\text { Vishunpurvariya, Bishunpura, } \\
\text { Padri kripal }\end{array}$ \\
\hline Bankati & $\begin{array}{l}\text { Datuakhore, Tharapar, } \\
\text { Bhasha Pandey }\end{array}$ & Roopaedeeh & $\begin{array}{l}\text { Chhitani, Bishaupur Belmariya, } \\
\text { Chauhata }\end{array}$ \\
\hline Bahadurpur & $\begin{array}{l}\text { Pokharni, Kondar, Kalwari, } \\
\text { Masaha }\end{array}$ & Itiyathok & Sisai, Belmariya, Bardeeha \\
\hline Kudraha & $\begin{array}{l}\text { Raj Pur Baira, Bamahi, } \\
\text { Paun, Lalganj }\end{array}$ & Mujehana & $\begin{array}{l}\text { Dhanapur, Bisambarpur, } \\
\text { Bhavanipur }\end{array}$ \\
\hline Harraiya & $\begin{array}{l}\text { Fardapur, Naryanpur, } \\
\text { Chhapia Bujurg, Divalarpur }\end{array}$ & Karnailganj & Kepani, Saraya, Naryanpur \\
\hline Vikram Jot & $\begin{array}{l}\text { Pachvas, Purahamraj, } \\
\text { Bachipur }\end{array}$ & Katra bazar & $\begin{array}{l}\text { Wanshbhariya, Pipri Gauriya, } \\
\text { Sarawanpur }\end{array}$ \\
\hline Parasrampur & $\begin{array}{l}\text { Sikandrpur, Loharauli, } \\
\text { Jitpur }\end{array}$ & Haldharmau & Kamalgalpur, Bataura, Devitilmaha \\
\hline Dubaulia & Rampur, Singharana, Pakhari & Paraspur & Khaira, Pakhake, Madhaipur \\
\hline Captanganj & Padmapur, Kudhava, Bantiara & Tarabganj & Shushla, Shaghia, Mauhari \\
\hline Gaur & $\begin{array}{l}\text { Aktakva, Pandav, Amodha, } \\
\text { Parasdeen }\end{array}$ & Belsar & $\begin{array}{l}\text { Sonauli Mohamadpur, Parsada, } \\
\text { Birsinghpur }\end{array}$ \\
\hline Rudhauli & $\begin{array}{l}\text { Sisawa, Rainagar, } \\
\text { Hamumanganj, Baskhor }\end{array}$ & Wazirganj & Achalpur, Jagdishpur, Dalbharia \\
\hline Ramnagar & $\begin{array}{l}\text { Bhanpur, Harihapur, Sonaha, } \\
\text { Narkhotia }\end{array}$ & Nawabganj & $\begin{array}{l}\text { Kishundas, Kalyanpur, Vishnu } \\
\text { Harpur }\end{array}$ \\
\hline \multirow[t]{3}{*}{ Saltaua } & $\begin{array}{l}\text { Gohnia, Muradpur, } \\
\text { Bhagwanpur, Maghua }\end{array}$ & Mankapur & $\begin{array}{l}\text { Vidyanagar, Manakapurkote, } \\
\text { Mangal Bhawan }\end{array}$ \\
\hline & & Babhanjot & $\begin{array}{l}\text { Sabanjot, Ghajipur, Pipri } \\
\text { Ismailpur, Baizpur }\end{array}$ \\
\hline & & Chhapiya & $\begin{array}{l}\text { Babhnikhas, Itwalbujurg, } \\
\text { Charu, Jirabhari }\end{array}$ \\
\hline
\end{tabular}


Present status of fish farming and pond conditions from Basti and Gonda districts, Uttar Pradesh

TABLE-2 Present status of fish farming in the districts - Basti and Gonda

\begin{tabular}{|c|c|c|c|}
\hline \multirow[t]{2}{*}{ S. No. } & \multirow[t]{2}{*}{ Informations } & \multicolumn{2}{|c|}{ Districts } \\
\hline & & Basti & Gonda \\
\hline 1. & Total geographical area of district $\left(\mathrm{km}^{2}\right)$ & 2688 & 4003 \\
\hline 2. & Total number of blocks & 14 & 16 \\
\hline 3. & Total number of ponds & 3848 & 4471 \\
\hline 4. & Total area of fish farming (ha) & 1040.42 & 3706.86 \\
\hline 5. & Total production of fish ( $\mathrm{t}$ ) & 1800 & 3850 \\
\hline 6. & Average production of fish (kg/ha) & 2800 & 3000 \\
\hline 7. & $\begin{array}{l}\text { Type of fish culture commonly used in } \\
\text { practice }\end{array}$ & $\begin{array}{l}\text { Composite fish } \\
\text { culture }\end{array}$ & $\begin{array}{l}\text { Composite fish } \\
\text { culture }\end{array}$ \\
\hline 8. & Area under composite fish culture (ha) & 1040.42 & 3706.86 \\
\hline $\begin{array}{l}\text { i) } \\
\text { ii) }\end{array}$ & $\begin{array}{l}\text { Species selected for composite fish } \\
\text { culture } \\
\text {-Indian Major Carps (IMC) } \\
\text { Exotic Carps (EC) }\end{array}$ & $\begin{array}{l}\text { IMC- } 3 \text { species: } \\
\text { Catla, Rohu, } \\
\text { Mrigal/Nain } \\
\text { EMC- } 3 \text { species: } \\
\text { Silver carp, Grass } \\
\text { carp, Common } \\
\text { carp }\end{array}$ & $\begin{array}{l}\text { IMC- } 3 \text { species: } \\
\text { Catla, Rohu, } \\
\text { Mrigal/Nain } \\
\text { EMC- } 3 \text { species: } \\
\text { Silver carp, Grass } \\
\text { carp, Common carp }\end{array}$ \\
\hline 10. & Length of rivers $(\mathrm{km})$ & 145.4 & 88.0 \\
\hline 11. & $\begin{array}{l}\text { Average production of fish } \\
\text { in rivers }(\mathrm{kg} / \mathrm{km})\end{array}$ & 2000 & 2500 \\
\hline 12. & Fish seed hatchery & $\begin{array}{l}\text { Govt. }-1 \\
\text { Private }-1\end{array}$ & $\begin{array}{l}\text { Govt. }-1 \\
\text { Private }-2\end{array}$ \\
\hline 13. & $\begin{array}{l}\text { Total number of fingerlings } \\
\text { supplied by FFDA (lakh/ year) }\end{array}$ & 135.00 & 158.00 \\
\hline
\end{tabular}

Source: FFDAs Basti and Gonda districts.

in the riverine fishery ${ }^{7,17,21}$. The gap between scientific and traditional system has been detected in grass root in present study. The aim of this study was to assess the pond size, pond type, ownership of the pond and structure of the fish culture from Basti and Gonda districts, Uttar Pradesh.

\section{Material and Methods \\ Selection of the districts}

The study was conducted in two districts namely Basti and Gonda of eastern Uttar Pradesh. These districts were selected purposively. The Basti district is divided 
TABLE-3: Distribution of the respondents according to pond size (area)

$\mathrm{N}=100$

\begin{tabular}{l|c|c|c|c|c|c}
\hline & & \multicolumn{4}{|c|}{ Respondents } & \\
\hline S.No. & Categories & \multicolumn{2}{|c|}{ Basti } & \multicolumn{2}{c}{ Gonda } & Total (\%) \\
\hline & & Number & $\%$ & Number & $\%$ & \\
\hline 1 & Below 1 ha & 26 & 52 & 25 & 50 & 51 \\
\hline 2 & $1-2$ ha & 19 & 38 & 16 & 32 & 35 \\
\hline 3 & Above 2 ha & 05 & 10 & 09 & 18 & 14 \\
\hline
\end{tabular}

into 14 blocks, whereas, the Gonda district has 16 blocks.

The criteria for selection of these districts were the close familiarity of investigator with respect to its area, people, officials, non-officials and local dialect. These districts were easily accessible to investigator too.

\section{Selection of villages}

For selection of villages list of all the villages of the respective blocks were prepared and three to four villages from each block were selected on the criteria of presence of large number of fish ponds in these villages. The selected villages for the study are given in the Table-1.

\section{Results and Discussion}

Table 2 indicates present status of the fish farming in the selected districts viz., Basti and Gonda. The total geographical areas are $2688 \mathrm{~km}^{2}$ and $4003 \mathrm{~km}^{2}$ in Basti and Gonda district, respectively. In both districts the composite fish culture technology is commonly followed for fish farming with six species combination i.e. Indian Major Carps (IMC) i.e. Catla catla (Catla), Labeo rohita (Rohu) and Cirrhinus mrigala (Mrigal/Nain) and Exotic Major Carps (EMC) i.e. Hypophthalmichthys molitrix (Silver carp), Ctenopharyngodon idella (Grass carp) and Cyprinus carpio (Common carp). There are 14 blocks in Basti district in which 3848 number of ponds are found. These ponds cover 1040.42 ha of water spread area. The total production of fish in district is 1800 ton/year and average production is $2800 \mathrm{~kg} / \mathrm{ha} /$ year. The total length of rivers flowing in Basti district is about $145.4 \mathrm{~km}$ and the average production of rivers is about $2000 \mathrm{~kg} / \mathrm{km}$. The number of fingerlings supplied by FFDA to the fish farmers is 135.00 lakh/year
(Table 2).

There are 16 blocks in Gonda district. The number of ponds is 4471 with water spread area of 3706.86 ha. The total fish production in the district is 3850 ton/year. The average fish production is $3000 \mathrm{~kg} / \mathrm{ha} / \mathrm{year}$. In Gonda district the length of rivers is about $88.00 \mathrm{~km}$ with an average fish production of $2500 \mathrm{~kg} / \mathrm{km}$. The number of fingerlings supplied by FFDA to the fish farmers is 158.00 lakh/year (Table 2).

The number of fish seed hatchery in Basti district is one each of government and private sector whereas, in Gonda district the number is one government and two private (Table 2).

\section{(i) Pond size (area)}

Table- 3 clearly indicates that the area of pond of $51 \%$ respondents was below 1 ha, followed by $35 \%$ respondents was from 1-2 ha and 14\% respondents was above 2 ha. The $52 \%$ respondents have less than 1 ha in the Basti district while $50 \%$ in Gonda district. Data also indicated that the fish farmers of both districts are marginal because they have smaller ponds (Table 3). The larger ponds (above $2 \mathrm{ha}$ ) were recorded maximum (18\%) in the Gonda district.

\section{(ii) Pond type}

It is clear from the data included in the below Table- 4 that culture ponds of the majority of the respondents (72\%) were managed type whereas, ponds of $28 \%$ of the respondents were unmanaged type.

Thus, it can be inferred that the majority of fish farmer adopted more than $50 \%$ of steps of composite fish culture technology. 
Present status of fish farming and pond conditions from Basti and Gonda districts, Uttar Pradesh

TABLE-4: Distribution of the respondents according to pond type

$\mathrm{N}=100$

\begin{tabular}{l|c|c|c|c|c|c}
\hline & & \multicolumn{4}{|c|}{ Respondents } & \\
\hline S.No. & Categories & \multicolumn{2}{|c|}{ Basti } & \multicolumn{2}{c}{ Gonda } & Total (\%) \\
\hline & & Number & $\%$ & Number & $\%$ & \\
\hline 1 & Managed pond & 34 & 68 & 38 & 76 & 72 \\
\hline 2 & Unmanaged pond & 16 & 32 & 12 & 24 & 28 \\
\hline & Total & $\mathbf{5 0}$ & & 50 & & 100 \\
\hline
\end{tabular}

\section{(iii) Pond ownership}

$76 \%$ respondents have leased ponds followed by $16 \%$ having their own ponds while only $8 \%$ respondents arranged ponds on rent basis from other owners (Table 5). The pond owner respondents were observed maximum number with $20 \%$ in the Gonda district (Table 5). But middle man (example rented respondents) also reported maximum with $10 \%$ in the Gonda district. Thus, it is concluded that the majority of fish farmers (76\%) have leased ponds from the revenue department. Gonda district has more potential for fish forming in future.

Study showed that Gonda district was the most active district as far as in fish farming is concerned and Basti district was found poor in fishery activities. Though the most of the water bodies existing in different villages are presently under fish farming but there is still immense scope for further expansion of farming activities as well as yield enhancement from each water body. It is very clear that political crucial and poor enforcements are major donors to fishery failures ${ }^{11,12,14,18}$. The fish farmers under different types of management were found to face with many technical (Example manuring, feeding, stocking density, seasonal diseases), economical and social problems ${ }^{1,27}$. The very poor technical knowledge is the major problem of pond fish production in the aquaculture practices $^{4,5,9}$. Aquaculture production models are highly dynamic with regional improvement ${ }^{20,23 .}$.

It may be concluded that the water resources of

TABLE-5: Distribution of the respondents according to pond ownership

$\mathrm{N}=100$

\begin{tabular}{l|c|c|c|c|c|c}
\hline & & \multicolumn{5}{|c|}{ Respondents } \\
\hline S.No. & Categories & \multicolumn{2}{|c|}{ Basti } & \multicolumn{2}{c}{ Gonda } & Total (\%) \\
\hline & & Number & $\%$ & Number & $\%$ & \\
\hline 1 & Owned & 06 & 12 & 10 & 20 & 16 \\
\hline 2 & Leased & 41 & 82 & 35 & 70 & 76 \\
\hline 3 & Rented & 03 & 06 & 05 & 10 & 08 \\
\hline
\end{tabular}


the both districts are sufficient. Traditional culture techniques were used by formers. Water and feeding management was not done properly (e.g., scientific). The data also indicated that the Gonda district has more potential in fish production compared to Basti district.

\section{References}

1. Ali MM, Hossain MB, Minar MH, Rahman S, Islam MS Socio-Economic Aspects of the Fishermen of Lohalia River, Bangladesh. Middle-East J. Scient. Res. 2014; 19(2):191-195.

2. Ayyappan S. Rich untapped reserves. The Hindu Survey of Indian Agriculture, Section 4 (Aquaculture), 2000; pp. 129-133.

3. Ayyappan S, Venkateshwarlu Production, much below potential : Inland fishery resource. The Hindu Survey of India, Agriculture. 2002; pp. 143-146.

4. Belton B, Karim M, Thilsted SH, Collis W, Phillips M. Review of aquaculture and fish consumption in Bangladesh. Food Nutrition Bulletin. 2011; 21: 482-487.

5. Biswas B, Das SK, Mandal A. Alterations in the management practices of composite farming of Indian Major Carps in 24 Parganas (N) district, West Bengal. J. Entomol. Zool. Stud. 2017; 5(6): 2656-2661.

6. Ch BP, Khairnar SO, Mandal A, Kumar A, Kumar B. Composite fish farming: A review on economic enterprise for rural empowerment and livelihood generation. Int. J. Fish. Aquat. Stud. 2018; 6(4): 545-550.

7. Dwivedi AC, Nautiyal P. Population dynamics of important fishes in the Vindhyan region, India. LAP LAMBERT Academic Publishing GmbH \& Co. KG, Dudweiler Landstr. 99, 66123 Saarbrucken, Germany. 2010; P. 220.

8. Dwivedi AC, Jha DN, Mayank P. Food security, livelihood and non-native fish species: status, trends and future Perspectives. Journal of the Kalash Science. 2014; 2(3) (Special Volume): 41-46.

9. Dwivedi AC, Jha DN, Shrivastava RS, Das BK, Mayank P, Kumar M, Tiwar A. Status of water resources and fish farming in Allahabad district, India. J. Fish. Livestock Prod. 2018; 6(2) 274. Doi. 10.4172/2332-2608.1000274.

10. Dwivedi AC, Mayank P, Tripathi S, Tiwari A. Biodiversity: the non-natives species versus the natives species and ecosystem functioning. Journal of Biodiversity, Bioprospecting and Development. 2017; 4(1): DOI: 10.4172/ 2376-0214.1000164.

11. Dwivedi AC, Tewari NP, Singh KR Present structure of capture and culture fishery of the Faizabad District (U.P.). Bioved. 2004; 15(1, 2): 95-98.

12. Fulton EA, Smith ADM, Smith DC, Van Putten IE. Human behavior: the key source of uncertainty in fisheries management. Fish and Fisheries. 2011.

13. Hague M. The economic and feasibility of aquaculture in Northern Tanzania. B.A. dissertation, University of Stirling, Scotland. 1992; p. 40.

14. Jha DN, Joshi KD, Dwivedi AC, Mayank P, Kumar M, Tiwar A. Assessment of fish production potential of Chitrakoot district, Uttar Pradesh. J. Kalash Sci. 2015; 3(3 Special Volume): 7-10.

15. Kumar J, Pandey AK, Dwivedi AC, Kumar NaikAS, Mahesh V, Benakappa S. Ichthyofaunal diversity of Faizabad district (Uttar Pradesh), India. J. Exp. Zool. India. 2013; 16(1): 149-154.

16. Mahmud S, Ali MI, Ali MM. Present Scenario on Livelihood Status of the Fishermen in the Paira River, Southern Bangladesh: Constraints and Recommendation. Int. J. Fish. Aquat. Stud. 2015; 2(4):23-30.

17. Mayank P, Dwivedi AC. Biology of Cirrhinus mrigala and Oreochromis niloticus. LAP LAMBERT Academic Publishing GmbH \& Co. KG, Dudweiler Landstr. 99, 66123 Saarbrucken, Germany. 2015; P. 188.

18. Mayank P, Dwivedi AC, Pathak RK. Age, growth and age pyramid of exotic fish species Oreochromis niloticus (Linnaeus 1758) from the lower stretch of the Yamuna river, India. Natl. Acad. Sci. Lett. 2018; 41(6): 345-348. doi.org/10.1007/s-40009-018-0673-7. 
19. Mishra P, Rao AP, Dwivedi AC, Mishra M, Upadhyay SK. Composite fish culture in district Faizabad: sociopersonal, economic and cultural constraints among fish farmers. Journal of Natural Resource and Development. 2007; 2(1): 32-37.

20. Mondal MAH, Begum K, Islam MR, Mitul ZF, Hossen S, Ali MM. Pond fish culture in Southwestern Bangladesh: An overview of the post stocking management practices. Int. J. Fish. Aquat. Stud. 2018; 6(1): 170-173.

21. Pathak RK, Gopesh A, Dwivedi AC. Invasion potential and biology of Cyprinus carpio (Common carp). LAP LAMBERT Academic Publishing GmbH \& Co. KG, Dudweiler Landstr. 99, 66123 Saarbrucken, Germany. 2015.

22. Roy K. Qualitative plankton diversity of a fish culture pond and a wild village pond of Chhattisgarh, South Central India. Global Res. Analy. 2012; 2: 13-14.

23. Shivakumar M, Bala S, Rajanna C, Naveenkumar BT. Economics of seed rearing and farming of carps. Int. J. Fish. Aquat. Stud. 2014; 2(1):42-45.

24. Tiwari A. Mayank P, Dwivedi AC. Assessment of human health risk via the consumption of the freshwater fish, Cyprinus carpio and Oreochromis niloticus from the Ganga River, India. Bioved. 2017; 28(2): 341-349.

25. Tripathi S, Gopesh A, Dwivedi AC. Fish and fisheries in the Ganga river : Current assessment of the fish community, threats and restoration. J. Exp. Zool., India. 2017; 20(2): 907-912.

26. Whitfield M, Biggs J, Bray S, Fox G, Nicolet P, ET Al. Comparative biodiversity of rivers, streams, ditches and ponds in an agricultural landscape in southern England. Biolog. Conser. 2004; 115: 329-341.

27. Zaman T, Jewel MAS, Bhuiyan AS. Present status of pond fishery resources and livelihood of the fish farmers of Mohanpur Upazila in Rajshahi district. Univ. J. Zool. Rajshahi Univ. 2006; 25: 31-35. 